\title{
ARTICLES
}

Submitted 02.04.2014. Approved 09.08.2016

Evaluated by double blind review process. Scientific Editor: Felipe Zambaldi

DOI: http://dx.doi.org/10.1590/So034-759020160608

\section{CREATIVE MARKETING STRATEGY AND EFFECTIVE EXECUTION ON PERFORMANCE IN PAKISTAN}

\author{
Estratégia de marketing criativo e execução efetiva sobre o seu desempenho \\ no Paquistão
}

\section{Estrategia de marketing creativo y ejecución efectiva sobre su desempeño en Paquistán}

\begin{abstract}
The purpose of the current research is to determine the influence of creative marketing strategies and effective execution on business unit performance. Moreover, strategic orientation and environmental uncertainty are used as moderating variables. Data are collected from 368 key informants working in Fast-Moving Consumer Goods (FMCG), banking, pharmaceutical, chemical, insurance, and engineering industries using a multi-stage random sampling technique. Factor analysis and multiple hierarchal regressions are used to test the study hypotheses. The results indicate that creative marketing strategy and effective execution are positively associated with business performance. Moreover, environmental uncertainty and strategic orientation play a moderating role in the above relationships.
\end{abstract}

KEYWORDS | Marketing strategy, creativity, strategic orientation, firm performance, Pakistan.

\section{RESUMO}

O objetivo da pesquisa é determinar a influência de estratégias de marketing criativo e execução efetiva no desempenho da unidade de negócios. Além disso, a orientação estratégica e incerteza ambiental são utilizadas como variáveis moderadoras. Os dados foram coletados de 368 informantes-chave que trabalham em indústrias Fast-Moving Consumer Goods (FMCG), no setor bancário, farmacêutico, químico, de seguros e engenharia com a ajuda da técnica de amostragem aleatória multi-etápica. Análise fatorial e regressão múltipla hierárquica foram empregadas para testar as hipóteses do estudo. Os resultados indicaram que a estratégia de marketing criativo e sua execução efetiva se associam positivamente ao desempenho dos negócios. Adicionalmente, a incerteza ambiental e a orientação estratégica desempenharam papel moderador nas relações analisadas.

PALAVRAS-CHAVE / Estratégia de marketing, criatividade, orientação estratégica, desempenho empresarial, Paquistão.

\section{RESUMEN}

El presente estudio tiene como objetivo determinar la influencia de las estrategias de marketing creativo y ejecución efectiva sobre el desempeño de unidades de negocio. Además, la orientación estratégica y la incertidumbre ambiental se utilizan como variables moderadoras. Los datos son recolectados de 368 informantes claves que trabajan en industrias Fast-Moving Consumer Goods (FMCG), banca, farmacéutica, química, seguros e ingeniería utilizando una técnica de muestreo aleatorio polietápico. Para probar la hipótesis del estudio, se utilizan análisis factorial y regresiones jerárquicas múltiples. Los resultados indican que la estrategia de marketing creativo y la ejecución efectiva están asociadas positivamente al desempeño de negocios. Además, la incertidumbre ambiental y la orientación estratégica desempeñan un papel moderador en las relaciones antes mencionadas.

PALABRAS CLAVE I Estrategia de marketing, creatividad, orientación estratégica, desempeño de firmas, Paquistán. 


\section{INTRODUCTION}

In order to compete in fast changing business environments, a set of skills is necessary to adopt, integrate, and exploit given resources effectively (Barney, 1991; Teece, Pisano, \& Shuen, 1997). Markides (1999) introduced "breakthrough strategies" that primarily focus on revitalizing business and markets in a competitive environment, also taking other strategic alliances into consideration. The combination of creative marketing strategies and effective implementation seems a logical approach for organizations to gain a competitive advantage. O'Reilly and Tushman (2004) claimed that very few firms, referred as "ambidextrous organizations," are flexible and risk taking, and believe in the exploration of innovation and experimentation in doing business, whereas some companies focus on execution, implementation, selective, efficient, and refined practices. These concepts are explained as exploration and exploitation, as introduced by Marsh (1991). In 2007, Business Week released an article by Hindo on ambidextrous organizations, where the author discussed several business management issues, taking $3 \mathrm{M}$ as an example. The link between creative marketing strategies and business performance is intuitive and convincing, but research focused on western countries has delivered mixed results, whereas no significant research has focused on the Asian context yet.

The first research conducted on the topic examined the antecedents of creative marketing and found a significant impact on business performance (Andrews \& Smith, 1996). These findings are further confirmed by another early study, Menon, Bharadwaj, Adidam, and Edison (1999). On the other hand, Im and Workman (2004) were unable to find any significant relationship between innovative marketing programs and business performance. Noble and Mokwa (1999) focused on the impact of effective strategy execution on performance. Vorhies and Morgan (2005) showed that firms with average performance cannot implement marketing strategies effectively when compared to high performing firms in competitive markets. Neilson, Martin, and Powers (2008) further argued that the implementation phase of any business strategy is not an easy task for senior marketing personnel. Hence, effective implementation is considered a major concern for practitioners (Bower \& Gilbert, 2007) and academicians (Chebat, 1999). The issue has been consistently labeled as implementation gap, black box strategy, and depicted as an elusive phenomenon (Bourgeois \& Brown, 1984; Miller, Wilson, \& Hick, 2004; Piercy, 2009).

A business strategy is the set of decisions that enables an organization to generate superior performance. Porter (1980) and Miles and Snow (1978) provided the most relevant theoretical framework to understand the nature of strategic decisions. Four archetypes of organizational approach are identified, depending on how a company defines its product-market realm (entrepreneurial problem), processes, and constructs structures (the technical and administrative problems) to achieve business realization. Organizations with Prospector orientation are readily involved in identifying a new market and product opportunities, whereas Defenders tend to create longstanding relationships with customers and products in the global market. On the other hand, Analyzers take a transitional approach, standing between Defenders and Prospectors, but actively tracking Prospectors for developing stable customer relationships and product range. Reactors, the last type, do not show a consistent reply to an entrepreneurial problem (Slater, Halt, \& Olson, 2010).

The entrepreneurial problem relates to how a product defines the market coverage scope (i.e., market or focused wide) and how an organization crafts customer values (i.e., low cost or differentiation strategy), as discussed in Porter, 1980.

In order to generate higher profits, organizations should define creative marketing strategies and have the ability to implement them effectively. Due to resource competition, uncertain environment, and cultural tensions, it is often hard to accomplish both objectives at the same time (Slater et al., 2010; Ishaq, 2013). For instance, The current economic and social situation in Pakistan has created an ambiguous and uncertain business environment that heavily damaged all business sectors, badly affecting marketing activities, and individual and organizational performance. Creative marketing strategies and effective implementation are well-documented constructs in academic literature due to their significance for the strategy development process. However, the academic literature is still vague on issues linked with creativity and creative strategies implementation. Therefore, this research provides a significant contribution to the literature by examining the simultaneous impact of creative marketing strategy and effective implementation on business unit performance. Moreover, environmental uncertainty and strategic orientations are tested as moderating variables.

\section{LITERATURE REVIEW}

In a competitive and fierce competition environment, organizations are actively developing overarching skills to build long-term strategies and plan their perfect execution (Noble \& Mokwa, 1999; Walker \& Ruekert, 1987). To achieve this goal, top marketing executives should focus on their businesses field to increase organizational performance (Slater \& Olson, 2000). While conducting research on business strategies and innovation, the first question a researcher faces is why organizations experience difficulties in adopting creativity and effective implementation simultaneously. March (1991) provided an explanation of this dilemma in terms of "exploration 
vs. exploitation conundrum." Exploration includes procedures like creativity, innovation, experimentation, and risk taking, whereas exploitation covers execution, efficiency, and implementation (Slater et al., 2010; Ishaq, 2013). In the next sections, we discuss the potential of creative marketing strategies and effective execution for increased business unit performance in uncertain environments and across strategic orientations.

\section{Marketing strategy creativity}

A creative marketing strategy is defined as a set of activities developed to promote products/services for selective or full target markets to achieve business objectives. For newcomers, the only way to stay in competition is to adopt an innovative strategy (Hamel, 1988). Marketing creativity is described as the steps into the conception of distinctive practices in the marketing department. An organization that has unique, creative, or innovative strategy can hold a strategic position in the industry and it is less likely to be imitated by competitors (Barney, 1991, Ishaq, 2013). Researchers (Bourgeois \& Eisenhardt, 1988; Menon et al., 1999) argued that firms only achieve positive goals if they believe in rigorous decisionmaking process, innovative solutions, and creative strategies. For instance, Cirque du Soleil is the best example of very creative or “Blue Ocean” strategy (Kim \& Mauborgne, 2004).

Innovative and creative businesses create new strategies, think innovatively, and strengthen their competitive space in the industry by satisfying their customers' demand (Slater et. al., 2010). Innovative strategies can comprise a new pricing model, value propositions, market expansion, customer driven policies, efficient supply chain, and other means for "reaching out to customers" (Ishaq, 2013). This marketing mix is the main reason for buyers to purchase a certain product/service, due to a differentiation in customer value that will lead to increased organizational performance. Therefore, we introduce the following hypothesis.

$\mathrm{H}_{1}$ : Creative marketing strategy exerts a positive impact on business performance.

\section{Strategy implementation effectiveness}

Bonoma (1984) asserts that, while creative and innovative strategies might be easier to conceive, their implementation with respect to customer constraints, competitors, and current organizational circumstances is often complicated. Noble and Mokwa (1999) define strategy implementation as the enactment of a given script and guidelines. Cespedes and Piercy (1996) consider effective execution as the accomplishment of organizational goals through appropriate actions. Many researchers focused on behavioral and interpersonal characteristics of strategy implementation (e.g., Noble \& Mokwa, 1999), where the academic literature suggests a few definitions. Wind and Robertson (1983) suggest a simple definition of marketing strategy implementation as "the operationalization of a clearly articulated strategic marketing plan."

Some researchers (Guth \& MacMillan, 1986; Floyd \& Wooldridge, 2000) argued that the effective implementation of a business strategy is a sole responsibility of mid-level managers, due to their precarious role and current market situation. Despite their crucial role, only a few studies addressed the drivers of a successful implementation of creative strategies by mid-level managers working in marketing departments (Bower \& Gilbert, 2007). Konovsky (2000) and Noble and Mokwa (1999) argued that organizational justice procedures are decisive factors, driving the efforts of the employees towards effective strategy implementation, as they are associated with clear communication strategy at the top management's end and organizational buy-in.

Nohria, Joyce, and Roberson (2003) conducted a research on 160 organizations observed over five years and concluded that organizations that implement their strategies flawlessly have a high likelihood to achieve market success. To realize an effective execution of marketing strategies, top management is responsible to provide human resources, financial resources, direction, and a competitive environment (Varadarajan, Jayachandran, \& White, 2001; Naeem, Nawaz, Rana, \& Ishaq, 2011; Ishaq, 2013). Hrebiniak (2005) identified the implementation concept as a key success factor for an organization due to its strategic implications, such as invisibility, competitive advantage, and difficulty in imitating faced by competitors. Numerous researchers devoted huge efforts to understand different strategic behaviors for effective execution, such as market orientation, innovation orientation, organization's structure, marketing program contents, and product market strategy for achieving higher market share and performance (Ishaq, 2013; Matsuno \& Mentzer, 2000; Slater \& Olson, 2000, 2001; Vorhies \& Morgan, 2003). Most researchers argued that true success in implementation is only achieved when an organization finds the right fit in organizational characteristics and strategy, which leads to superior performance. Hence, we introduce the following hypothesis.

$\mathrm{H}$ 2: Effective implementation of marketing strategy leads to superior business performance of an organization.

\section{Tension between creativity \& implementation in uncertainty}

Researchers have tried to describe why organizations face harsh difficulties to achieve success on creativity and its implementation phase simultaneously. In his pioneer researcher, 
Abernathy (1978) discussed when and how an organization can generate innovative ideas and simultaneously increase its productivity. The tension between creativity and implementation is further addressed in a seminal work by March (1991), where the author analyses the exploitation vs. exploration conundrum describing exploration as the process of innovation, experimentation, risk taking, and creativity, whereas exploitation encompasses execution, implementation, and efficiency. Deshpande and Webster (1989) argued that culture is a deep-seated set of beliefs and values that translates into specific norms to transform an individual behavior in organizations. Quinn and Rohrbaugh (1983) offered a model for organization culture named "competing values," which consists of three dimensions: means-end, control-flexibility, and internal-external. The representation of culture along these dimensions produce four major types: (1) adhocracy, which is an external orientation consisting of flexibility, creative behavior, and entrepreneurial nature; (2) hierarchy, which is an internal orientation based on stability in business operations and produces predictability in businesses; (3) market, which represents stability, but in an external orientation situation with focus on competitive behavior, and (4) clan, which is an internal point of reference for an organization, and is explained in terms of flexibility and relationship building orientation (Slater et al., 2010).

Based on the above explanation, organizations characterized by adhocracy culture are expected to introduce creative strategies, whereas organizations characterized by hierarchy cultural orientation are expected to be oriented towards effective implementation. However, research provided conflicting evidence regarding the beliefs and values associated with hierarchy and adhocracy culture (Deshpande, Farley \& Webster, 1993). There seem to be a significant challenge to intermingle the values and beliefs of these two competing cultures into one another for establishing ambidextrous organizations. It seems that creativity and effective execution can simultaneously achieve satisfactory results only when addressing mediocrity rather than excellence (Slater et al., 2010). It is possible that organizations focusing on both strategies at the same time may lack internal fit or may be out of focus. Therefore, these organizations should be given an implicit and explicit choice to focus either on innovation or on implementation. Hence, we introduce the following hypotheses.

$\mathrm{H}_{3}$ : Creative marketing strategy plays a vital role in boosting business performance in an unpredictable environment.

$\mathrm{H}_{4}$ : Effective strategy implementation strongly influences business performance in predictable environments.

\section{Strategic orientation as moderating role}

Strategic action can play a role in both internal and external environments, in which a business firm is operating (Slater et al., 2010). Several empirical studies investigated the environment's impact (Jaworski \& Kohli, 1993; Slater \& Narver, 1994) on different product-market strategies (Ishaq, 2013; Matsuno \& Mentzer, 2000; Naeem et al., 2011; Naeem, Nawaz, \& Ishaq, 2012; Vorhies \& Morgan, 2003). To understand a strategic decision, Porter (1980) and Miles and Snow (1978) introduced a set of dominant typologies. In 1978, Miles and Snow recognized four prototypes of organizations, depending on how they describe their product-market realm and their approaches to it (entrepreneurial issues), and construct structures and processes (the technical and administrative issues) in a competitive market. This entrepreneurial behavior is further analyzed in Walker and Ruekert (1987), in which the authors categorized Defenders as Low Cost and Differentiated Defenders. To build a strong position in competitive economies, the highly creatively oriented Prospectors deal with innovative ideas; Analyzers focus on Prospector strategies and improve their status relatively (Dickson, 1992), while Differentiated and Low-Cost Defenders are late followers and risk averse and should grasp the advantages of consumers' preferences for superior and low cost services (Dickson, Farris, \& Verbeke, 2001).

\section{Prospector}

Prospectors, the first archetype proposed by Miles and Snow, are exploiting the situation, and locate market opportunities and new product development strategies on a regular basis. Prospectors express the highest entrepreneurial strategic orientation, characterized by high risk taking propensity and ability to fulfill the emerging markets demand. Aggressive marketing strategies are consistent with the market demand of the early adopter segment, as well as with the characteristic of innovative providers of unique services/products. These organizations have the ability to handle risk due to uncertainty and turbulent markets. They use marketing research extensively, which allows them to examine multiple aspects of market conditions. Miles and Snow (1978) argued that Prospectors rely on a "capacity to monitor a wide range of environmental conditions, trends, and events."

Organizations with an entrepreneurial mindset or Prospector orientation are recognized as dominant strategy makers, rather than implementers. Miller (1983) describes Prospectors as proactive innovators, first to come up with 
unique ideas, take risky steps for creating ventures and also engage in product-market innovation. They have the proper vision to achieve supporting goals, which represents a marketing strategy that not only inspires individuals, but also provides key directions to entrepreneurial organizations (Slater et al., 2010). Prospectors operate in the most competitive environment and satisfy latent customer needs on an immediate basis by offering new products and services (Slater et al., 2010). They have a proactive orientation towards the market (Narver, Slater, \& MacLachlan, 2004), especially towards the early adopter segment and innovators (Slater, Hult, \& Olson, 2007), which leads them to devote significant resources to drafting creative strategies, marketing research, and other related issues (Walker et al., 2003). Buyers in these special segments opt for a unique pricing model to reduce risk. As aggressive marketers (Slater \& Olson, 2001), Prospectors should develop multiple distributions to get a sustainable advantage in competing market (Moore, 1991). Hence, we introduce the following hypothesis.

$\mathrm{H}_{5}$ : For Prospectors, creative marketing strategies influence business performance more than an effective strategy implementation.

\section{Analyzers}

Analyzers stand in between the extreme positions of Prospectors and Defenders, and combine the strength of both strategies to maintain a stable customer base (Slater et al., 2010). The culture of Analyzers is a mixture of hierarchal and market culture. Market culture translates in competitor driven strategies, encourages consumer creativity, competitive values, and is outward looking. These facets are vital factors that allow these organizations to improve their product and service and compete with Prospectors. In these organizations, hierarchal culture is endorsed on execution, stability, and control on what an organization is currently working on or planning to achieve in the future. Organizations characterized by Analyzer orientation mainly focus on mass marketing strategies addressing the early majority and early adopter consumers by offering superior products, as compared to Prospectors. Slater et al. (2010) claimed that Analyzers quickly follow the Prospectors' strategies to attract new customers through the introduction of improved services and products with low cost. Analyzers can rapidly compete with Prospectors in terms of price, features, and quality, or a combination of these factors, to gain a larger market share. Therefore, Analyzers must prepare themselves to change their strategies quickly to reap more benefits in the market (Slater et al. 2010).
Miles and Snow (1978) claimed that Analyzers can achieve substantial growth with a combination of market and product development. Moore (1991) argued that buyers in this segment put a large emphasis on getting a complete and accurate solution to problems that may occur. Slater et al. (2010) argued that, if an organization is unable to implement its business plan effectively, the whole efforts of marketing activities lead to no result. Analyzers, based on their cultural orientation, are only able to achieve a "cross the chasm" status if they focus on innovative strategies and effective execution simultaneously (Moore, 1991). Slater and Olson (2001) argued that Analyzers have the ability to develop a strong and broad relationship with all strategic partners (distributors, retailers, wholesalers, raw material providers). Moreover, Analyzers usually take a balanced approach in competitive environments (Miles \& Snow, 1978). Therefore, we introduce the following hypothesis.

H6: For Analyzers, creative marketing strategies and effective strategy implementation equally contribute to increasing business performance.

\section{Low-cost Defenders}

Successful organizations with Low-Cost Defenders strategic orientation are characterized by a hierarchal culture, which pushes them to offer operational excellence and reasonable cost (Ishaq, 2013). This type of defenders minimizes the costs of their marketing strategy to achieve superior performance over competitors. Organizations competing with Low-Cost Defenders differentiate themselves through lowest price strategies with adequate product/service benefits. VIZIO is the best example of Low-Cost Defender: it was a consulting firm in 2004 and became a market share leader (LCD TVs domain) in the second quarter of 2007. VIZIO achieved this success through a low cost manufacturing process, intensive distribution strategy, low advertising, reasonably good quality, and low consumer price (Ogg \& Kanellos, 2007). Low-Cost Defenders engage in low-cost marketing activities, and focus on implementing their marketing strategy rather than designing innovative strategies. Therefore, we introduce the following hypothesis.

H7: For Low Cost Defenders, effective strategy implementation is more strongly associated with business performance than creative marketing strategy.

\section{Differentiated Defenders}

Differentiated Defenders are players who focus on late and early majority customers introducing quality services/products in the 
market. The only way for Differentiated Defenders to generate the maximum profit from the business is to differentiate themselves heavily, providing superior services/products and other advantages. Some Differentiated Defenders are working in product or service oriented industries, using pre-sale and post-sale strategies to differentiate from competitors. These organizations must establish a unique market proposition and an exclusive customer base to be able to charge higher prices (Ishaq, 2013; Slater \& Olson, 2001). Zeithaml et al. (1988) argued that providing better service quality includes control processes implementation and internal communication to manage employees in services organization. Successful Differentiated Defenders engage in relative formal policies and put constant emphasis on execution to ensure consistent service and product delivery (Olson, Slater, \& Hult, 2005a). Therefore, we introduce the following hypothesis.

H8: For Differentiated Defenders, creative marketing strategies and effective strategy implementation equally contribute to business performance boost.

\section{RESEARCH METHOD}

The sample for this study is drawn from two stock exchanges, Lahore Stock Exchange and Karachi Stock Exchange. In an initial step, eight sets of industries are formed, from both stock exchanges, for random sampling purpose. After stratification, 700 companies are randomly selected and a questionnaire based survey is conducted, sending the survey along with a cover letter to key informants, such as Business Unit Heads, Marketing Heads, Sales Head, National Sales Managers, and Brand Managers, across industries in Pakistan. In the first phase of data collection (eight weeks), 290 questionnaires have been received. Subsequent reminders yielded another one 105 questionnaires in four weeks. A total of 27 questionnaires are excluded from the study because of errors and missing values, and 368 questionnaires are completed, with a response rate of $52 \%$. To deal with non-response bias, an exploration technique is employed, as prescribed by Armstrong and Overton (1977). In this technique, the means of all study variables of the first and last third of respondents are compared; the results indicated no statistical differences in the mean scores. As the results show no statistical difference between late and early responses, we can conclude that the non-response biases are not a concern (Armstrong \& Overton, 1977). The list of all industries is available in Table 1.
Table 1. Companies that participated in the study

\begin{tabular}{l|c}
\hline \multicolumn{1}{c|}{ Industries } & $\begin{array}{c}\text { Number of companies / } \\
\text { Business units }\end{array}$ \\
\hline Insurance industry & 35 \\
\hline Banking industry & 43 \\
\hline Chemical industry & 44 \\
\hline FMCG industry & 60 \\
\hline Pharmaceutical industry & 19 \\
\hline Engineering industry & 31 \\
\hline Textile industry & 126 \\
\hline Telecommunication & 10 \\
\hline
\end{tabular}

Marketing strategy creativity is measured on a 10 item scale developed by Andrews and Smith (1996), while strategy implementation effectiveness is measured on a 5 item scale, as suggested by Noble and Mokowa (1999). Relative quality and relative cost are assessed on 3 items developed by Slater et al., (2010). Market turbulence and technology turbulence are assessed on 5 items, while competitive intensity is measured on a 6 item scale, as in Jaworski and Kohli (1993). Slater and Olson (2000) suggested one item scale for each strategic orientation (Prospectors, Analyzers, Differentiated Defenders, Low-Cost Defenders, and Rectors). Business performance is assessed according to the scale introduced by Olson et al. (2005a). First order reflective scales are used to measure all constructs, while the same constructs in uncertain environment are measured using a second order reflective scale. Environmental uncertainty is defined as the unpredictability of consumer behavior and technological innovation (Miller, Droge, \& Toulouse, 1988). Hence, environmental uncertainty refers to first order competitive intensity, market turbulence, and technology turbulence. All items are measured on a 5 point Likert scale, where $1=$ Strongly Disagree, 2 = Disagree, $3=$ Neutral, $4=$ Agree, and $5=$ Strongly Agree, except strategic orientation.

\section{RESULTS}

Table 2 reports the descriptive statistics, reliability coefficients, and exploratory factor analyses of each construct. The Cronbach's alpha coefficients of the study constructs range from 0.65 to 0.87 , whereas the threshold of the alpha coefficients is 0.60 James, Demaree, \& Wolf, 1984). This criterion is met by all variables. All constructs show an adequate level of internal consistency, and 
factor analysis is applied on each construct. The interpretability criterion of factor analysis is that at least 3 items of each construct show significant loadings (>0.30) (Cattell, 1966). Since the loading range of each construct is above o.30, all items are introduced in the analyses. Kaiser-Meyer-Olkin (KMO) and Bartlett's Tests are performed to examine the construct validities. The value of KMO, between 0.5 and 1.0, shows the appropriateness of the factor analysis, indicating that this type of data may be used for exploratory factor analysis. Furthermore, the Bartlett's Test also confirmed the statistical significance $(p<0.000)$ of each construct.

\section{Table 2. Descriptive statistics}

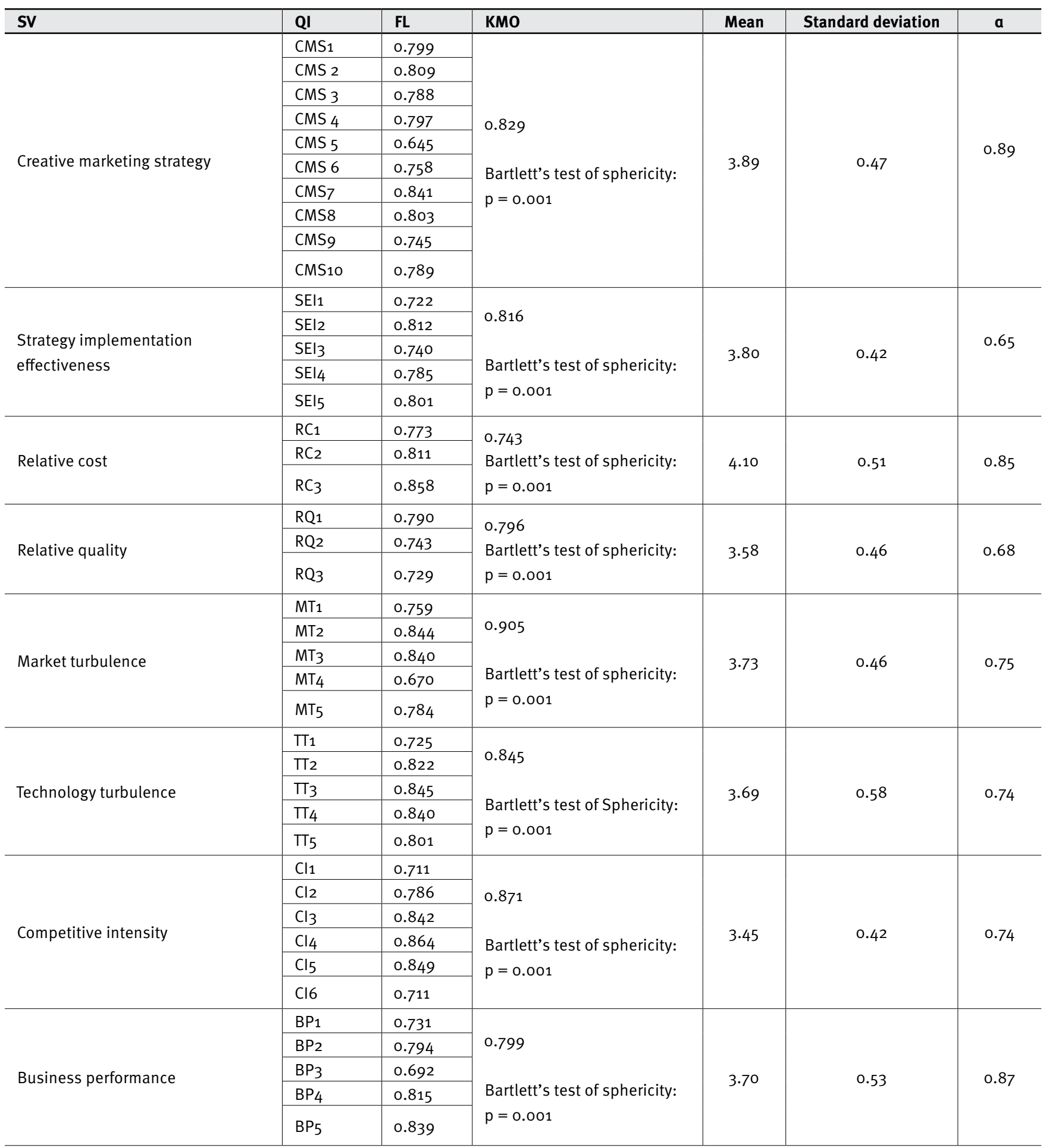


Table 3 reports the correlation and multicollinearity statistics of all study variables. Correlation values range between a minimum 0.28 to maximum 0.45 , indicating the absence of multicollineraity (Neter et al., 1983). Furthermore, variance inflation factors and tolerance statistics are also taken into consideration to address potential multicollinearity and we found values well below the threshold, confirming the absence of multicollinearity. Table 4 shows the stepwise regression analyses to test the hypothesis 1-4 of this research. In the first step of the hierarchal regression, a set of control variables is introduced in the model. The model explained $15 \%$ of the total variance and only environmental uncertainty (which is the product of three variables: technology turbulence, market turbulence, and completive intensity) showed positive and significant relationship with business unit performance. In the second step, two independent variables, creative marketing strategy (CMS) and strategy effective implementation (SEI), are introduced in the model and the model reflected $33 \%$ of the variance of the dependent variable. With respect to the predictive strength of the model, the ANOVA results confirmed that the model $(F=$ 98.677, $p=0.01$ ) is adequate to explain the variability of business performance. The beta coefficients showed a positive impact of creative marketing strategy $(\beta=0.349, t=2.96, p=0.01)$ and strategy effective implementation $(\beta=0.42, t=4.85, p=0.01)$ on business unit performance. Hence, the first two hypotheses of the study are confirmed.

\section{Table 3. Correlation statistics}

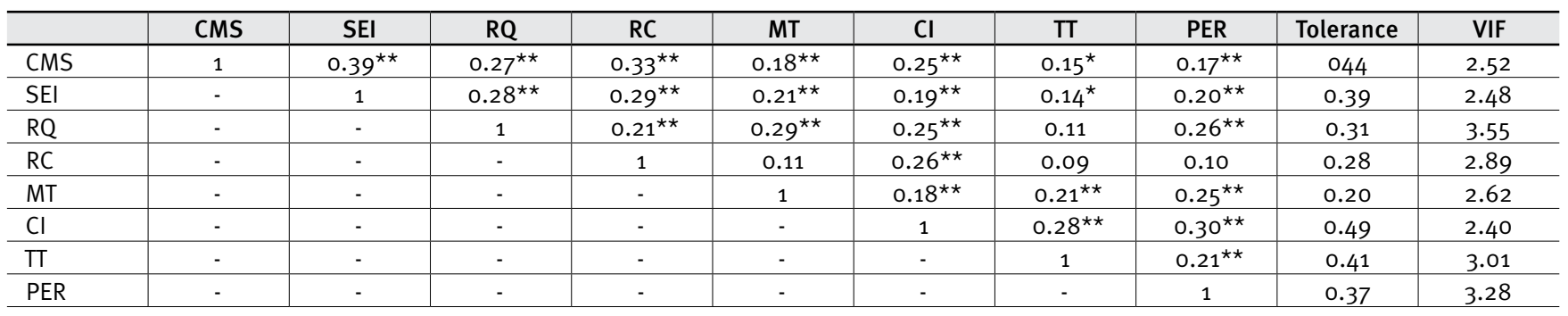

Note: Creative Marketing Strategy (CMS), Strategy Effective Implementation (SEI), Relative Cost (RC), Relative Quality (RQ), Technology Turbulence (TT), Market Turbulence (MT), Competitive Intensity (CI), Performance (PER).

*Significant at the 0.05 level (1-tailed); **Significant at the 0.01 level (1-tailed).

The moderating role of environmental uncertainty is also measured within the CMS/performance and SEI/performance relationships. The interaction term of CMS with environmental uncertainty and SEI with environmental uncertainty are entered in the model, which explained $30 \%$ of the variance of the dependent variable $(F=63.55, p=0.01)$. The results confirm that environmental uncertainty plays a moderating role in the CMS/performance $(\beta=0.40, t=4.49, p=0.01)$ and SEI/ performance relationships $(\beta=0.37, t=3.12, p=0.01)$. The results partially confirm our study hypotheses that creative marketing strategy plays a more important role in increasing business performance in uncertain environment conditions, whereas strategy implementation effectiveness has a stronger influence on business performance in a certain environment.

\section{Table 4. Regression analysis results}

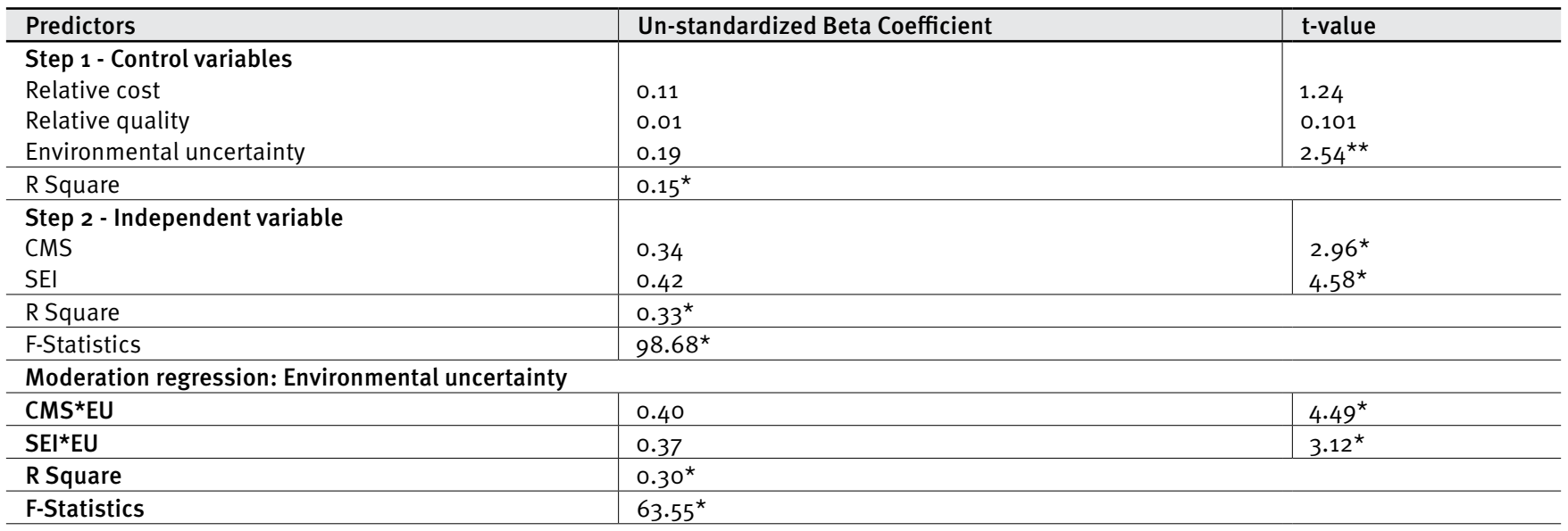

Note: Dependent Variable = Business Unit Performance, EU = Environmental Uncertainty (competitive intensity, technology and market turbulence).

* Significant at 0.01 levels: One-tailed, ** Significant at 0.05 levels: One-tailed. 
Table 5 reports the statistics on the moderating role of strategic orientation in creative marketing strategy, strategy implementation effectiveness, and business performance. For Prospector's strategic orientation, CMS and SEI explained $22 \%$ of the variance in the model, while the beta coefficients showed a stronger impact of SEl on the dependent variable $(\beta=0.463, t=$ $3.77, p=0.01)$, as compared to the impact of $C M S(\beta=0.368, t=$ $3.038, p=0.01$ ). These findings contradict the study hypothesis on
Prospectors. With respect to Analyzer's strategic orientation, CMS and SEl explained $28 \%$ of the variability in business performance, while beta coefficients showed a stronger impact of SEI on the dependent variable $(\beta=0.5444, t=4.63, p=0.01)$, as compared to CMS $(\beta=0.324, t=2.44, p=0.05)$. These findings also contradict the study hypothesis on Analyzers, as CMS and SEl were expected to have a similar impact on business unit performance.

\section{Table 5. Moderating regression analyses results}

\begin{tabular}{|c|c|c|c|c|}
\hline & Prospectors & Analyzers & Differentiated defenders & Low cost defenders \\
\hline & $(N=54)$ & $(N=53)$ & $(\mathrm{N}=39)$ & $(\mathrm{N}=43)$ \\
\hline & Beta (t-value) & Beta (t-value) & Beta (t-value) & Beta (t-value) \\
\hline \multicolumn{5}{|l|}{ Step 1: } \\
\hline Relative quality & $0.14(1.42)$ & $0.11(1.66)$ & $0.33(1.47)$ & $0.14(1.23)$ \\
\hline Relative cost & $0.05(0.53)$ & $0.14(0.41)$ & $0.26(0.63)$ & $0.04(0.10)$ \\
\hline EU & $0.15\left(2.15^{\star \star}\right)$ & $0.23\left(2.37^{\star \star}\right)$ & $0.29\left(2.03^{\star}\right)$ & $0.23\left(2.84^{\star}\right)$ \\
\hline \multicolumn{5}{|l|}{ Step 2: } \\
\hline CMS & $0.36\left(3.03^{\star}\right)$ & $0.32\left(2.44^{\star}\right)$ & $0.19(1.17)$ & $0.48\left(3.56^{\star}\right)$ \\
\hline SEI & $0.46\left(3.77^{\star}\right)$ & $0.54\left(4.63^{\star}\right)$ & $0.34\left(2.20^{\star}\right)$ & $0.24\left(2.35^{\star \star}\right)$ \\
\hline R Square & $0.22^{\star}$ & $0.28^{*}$ & $0.118^{\star \star}$ & $0.21^{*}$ \\
\hline F- Statistics & $14.25^{*}$ & $21.48^{\star}$ & $4 \cdot 92^{\star \star}$ & $12.36^{*}$ \\
\hline
\end{tabular}

Note: Dependent Variable = Business Unit Performance, EU = Environmental Uncertainty (competitive intensity, technology and market turbulence).

* Significant at 0.01 levels: One-tailed, ** Significant at 0.05 levels: One-tailed.

For Differentiated Defenders, CMS and SEl explained $12 \%$ of the variance in the model $(F=4.928, p=0.05)$. The beta coefficients showed a stronger impact of SEI on business performance ( $\beta=$ $0.343, t=2.20, p=0.05$ ), whereas the coefficient on CMS is not statistically significant. These findings are consistent with the study hypothesis for Differentiated Defenders, as SEI was expected to have a larger impact on business performance than CMS. For Low-Cost Defenders, CMS and SEI explained $21 \%$ of the variance in the model $(F=12.360, p=0.01)$, which seems adequate to explain the variability of business performance. The beta coefficients showed a stronger impact of CMS on business performance $(\beta=0.481, t=3.516, p=0.01)$, as compared to SEI $(\beta=0.245, t=2.355, p=0.05)$. These findings contradict the study hypothesis on Low-Cost Defenders.

\section{DISCUSSION AND CONCLUSION}

The results of this study indicate that CMS (adjusted $\mathrm{R}$ square $=$ $0.14, \beta=0.349, t=2.96, p=0.01$ ) and $\mathrm{SEl}$ (adjusted $\mathrm{R}$ square $=$
$0.10, \beta=0.42, t=4.85, p=0.01$ ) are significantly and positively associated with business performance in Pakistani industries. The results further confirmed that environmental uncertainty plays a moderating role in CMS/performance $(\beta=0.40, t=4.49, p=$ 0.01) and SEl/performance relationships $(\beta=0.37, t=3.12, p=$ $0.01)$. Prospector orientation organizations have the ability to develop creative strategies to achieve higher performance, as compared to effective execution. However, the results indicate that SEI has a stronger impact $(\beta=0.463, t=3.77, p=0.01)$ on business performance, as compared to CMS $(\beta=0.368, t=$ 3.038, $p=0.01$ ) in Pakistani industries. In firms characterized by Analyzer strategic orientation, SEI has a stronger impact $(\beta=$ $0.5444, t=4.63, p=0.01$ ) in boosting business performance, as compared to CMS ( $\beta=0.324, t=2.44, p=0.05)$. Differentiated Defenders put more emphasis on SEI to promote business unit performance (adjusted $\mathrm{R}$ square $=0.118, \beta=0.343, \mathrm{t}=2.20, \mathrm{p}=$ 0.05 ), as compared to CMS, which has no significant impact on performance. For Low-Cost Defenders, CMS has a stronger impact on business performance (adjusted $\mathrm{R}$ square $=0.213, \beta=0.481, \mathrm{t}=$ 3.516, $p=0.01)$, as compared to SEI $(\beta=0.245, t=2.355, p=0.05)$. 
This study produced some unique, unexpected, and interesting findings with respect to Pakistani industries. The results showed that creative marketing strategies and effective execution have a positive impact on performance across diversified industries operating in Pakistan. This work complemented previous research findings, where different researchers identified the importance of creativity and implementation for performance enhancement (Ishaq, 2013; Slater et al., 2010; Walker \& Ruekert, 1987). To the best of our knowledge, this is the first study of its kind that focuses on Asia, especially on the Pakistani context, and (1) utilizes the Walker and Ruekert's (1987) model for differentiating between Differentiated Defenders and Low-Cost Defenders; (2) addresses the impact of environmental uncertainty in highly unpredictable business markets, such as Pakistan.

In the highly competitive environment in which current businesses operate, it is hard to recognize the factors through which an organization creates innovative marketing strategies and plan their effective execution. Innovation in marketing strategies can only evolve with the help unique organizational characteristics and effective planning, and need to be further implemented to achieve good results. Research findings (for reference see Andrews \& Smith, 1996; Ishaq, 2013; Salter et al. 2010) showed that creative marketing programs have the ability to influence individual factors, but also situational forces, such as low time pressure, formal planning process, organizational processes, formal business education, macro-environment, and manager's knowledge of different business operations. In another study, Menon et al. (1999) reported that communication quality and integration among cross function teams are positively influenced by creative marketing programs. Kirca et al. (2006) conducted a meta-analysis on market orientation's antecedents and consequences and claimed that market orientation is strongly linked with innovativeness. This result suggests that marketoriented organizations with creative strategies are well focused on consumers' latent needs. Noble and Mokwa (1999) are considered the first authors to analyze the antecedents of effective implementation and concluded that the relationship between marketing strategy and a strategy effective implementation and the vision of the organization is mediated by the managers' commitment.

On the other hand, different researches assessed the interaction between marketing organizational structures and product-market strategies (Olson, Slater, \& Hult, 2005b), and performance and market orientations (Ishaq, 2013; Matsuno \& Mentzer, 2000; Slater et al., 2010; Vorhies \& Morgan, 2003). However, no study has ever taken into consideration organizational characteristics across different geographies. This research produced some important facts and figures relative to the Asian market. Although it surely has multiple strategic implications, this research also has some limitations. The study is based on the survey method and cross-sectional research design. Hence, researchers should take the study design into consideration while interpreting the study results. Future research should undertake longitudinal research to investigate the causal inference among the study variables. In addition, a single respondent from each business unit/organization has been addressed, which is an important limitation. Future research should use multiple raters from the same organizations, which will enhance the reliability of the results as "less knowledgeable informants can actually decrease the accuracy of responses" (Huber \& Power, 1985).

\section{REFERENCES}

Abernathy, W. J. (1978). The productivity dilemma: Roadblock to innovation in the automobile industry (Vol. 35): Johns Hopkins University Press Baltimore, MD.

Andrews, J., \& Smith, D. C. (1996). In search of the marketing imagination: Factors affecting the creativity of marketing programs for mature products. Journal of Marketing Research, 33(2), 174-187. doi:10.2307/3152145

Armstrong, J., \& Overton, T. (1977). Estimating nonresponse bias in mail surveys. Journal of Marketing Research, 14(3), 396-402. doi: $10.2307 / 3150783$

Barney, J. (1991). Firm resources and sustained competitive advantage. Journal of Management, 17(1), 99-120. doi:10.1177/014920639101700108

Bonoma, T. V. (1984). Making your marketing strategy work. Harvard Business Review, 62(2). Retrieved from https://hbr.org/

Bourgeois, L. J., \& Brodwin, D. R. (1984). Strategic implementation: Five approaches to an elusive phenomenon. Strategic Management Journal, 5(3), 241-264. doi:10.1002/smj.4250050305

Bower, J. L., \& Gilbert, C. G. (2007). How managers' everyday decisions create-or destroy-your company's strategy. Harvard Business Review, 85(2). Retrieved from https://hbr.org/

Cattell, R. B. (1966). The scree test for the number of factors. Multivariate Behavioral Research, 1(2), 245-276. doi:10.1207/s15327906mbro102_10

Cespedes, F. V., \& Piercy, N. F. (1996). Implementing marketing strategy. Journal of Marketing Management, 12(1-3), 135-160. doi:10.1080/02 67257X.1996.9964405

Chebat, J.-C. (1999). Special issue on strategy implementation and assessment research: Research on implementation deserves as much attention as strategy formulation. Journal of Business Research, 45(2), 107-109. doi:10.1016/S0148-2963(97)00229-4

Deshpande, R., \& Webster Jr, F. E. (1989). Organizational culture and marketing: Defining the research agenda. Journal of Marketing, 53(1), 3-15. doi:10.2307/1251521

Dickson, P. R. (1992). Toward a general theory of competitive rationality. Journal of Marketing, 56(1), 69-83. doi:10.2307/1252133 
Dickson, P. R., Farris, P. W., \& Verbeke, W. J. (2001). Dynamic strategic thinking. Journal of the Academy of Marketing Science, 29(3), 216237. doi:10.1177/03079459994605

Guth, W. D., \& MacMillan, I. C. (1986). Strategy implementation versus middle management self interest. Strategic Management Journal, 7(4), 313-327. doi:10.1002/smj.4250070403

Hamel, G. (1998). Opinion: Strategy innovation and the quest for value. MIT Sloan Management Review, 39(2). Retrieved from http://sloanreview.mit.edu/

Hindo, B. (2007). At 3M, a struggle between efficiency and creativity. Business Week, 11. Retrieved from http://www.bloomberg.com/businessweek

Hrebiniak, L. G. (2005). Making strategy work: Leading effective execution and change. New Jersey, USA: Pearson Education.

Im, S., \& Workman Jr, J. P. (2004). Market orientation, creativity, and new product performance in high-technology firms. Journal of Marketing, 68(2), 114-132. doi:10.1509/jmkg.68.2.114.27788

Ishaq, M. I. (2013). Marketing Strategy and business unit performance: Empirical evidence from Pakistani industries. Saarbrücken, Germany: LAP Lambert Academic Publishing.

James, L. R., Demaree, R. G., \& Wolf, G. (1984). Estimating within-group interrater reliability with and without response bias. Journal of $A p$ plied Psychology, 69(1), 85-98. doi:10.1037/0021-9010.69.1.85

Jaworski, B. J., \& Kohli, A. K. (1993). Market orientation: Antecedents and consequences. Journal of Marketing, 57(3), 53-70. doi: $10.2307 / 1251854$

Kim, W. C., \& Mauborgne, R. (2004). Blue ocean strategy. Harvard Business Review, 10. Retrieved from https://hbr.org/

Konovsky, M. A. (2000). Understanding procedural justice and its impact on business organizations. Journal of management, 26(3), 489511. doi: $10.1177 / 014920630002600306$

March, J. G. (1991). Exploration and exploitation in organizational learning. Organization Science, 2(1), 71-87. doi:10.1287/orsc.2.1.71

Markides, C. (1999). Six principles of breakthrough strategy. Business Strategy Review, 10(2), 1-10. doi:10.1111/1467-8616.00096

Matsuno, K., \& Mentzer, J. T. (2000). The effects of strategy type on the market orientation-performance relationship. Journal of Marketing, $64(4), 1-16$

Menon, A., Bharadwaj, S. G., Adidam, P. T., \& Edison, S. W. (1999). Antecedents and consequences of marketing strategy making: A model and a test. Journal of Marketing, 63((2), 18-40. doi:10.2307/1251943

Miles, R. E., \& Snow, C. C., (1978). Organizational strategy, structure, and process. New York: McGraw-Hill.

Miller, D., Dröge, C., \& Toulouse, J.-M. (1988). Strategic process and content as mediators between organizational context and structure. Academy of Management Journal, 31(3), 544-569.

Miller, S., Wilson, D., \& Hickson, D. (2004). Beyond planning: Strategies for successfully implementing strategic decisions. Long Range Planning, 37(3), 201-218. doi:10.1016/j.lrp.2004.03.003

Moore, G. (1991). Crossing the chasm: Marketing and selling technology products to mainstream customers. New York, USA: HarperBusiness.

Moorman, C., \& Miner, A. S. (1998). The convergence of planning and execution: Improvisation in new product development. Journal of Marketing, 62(3), 1-20. doi:10.2307/1251740
Naeem, B., Nawaz, M. M., \& Ishaq, M. I. (2012). Implications of marketing strategy for prospectors, analyzers and defenders. African Journal of Business Management, 6(4), 1527-1531. doi:10.5897/ajbm11.2294

Naeem, B., Nawaz, M. M., Rana, A. A., \& Ishaq, M. I. (2011). Do creative marketing strategy and its effective execution promote business performance? An empirical assessment. African Journal of Business Management, 5(30), 12108-12113. doi:10.5897/ajbm11.1154

Narver, J. C., Slater, S. F., \& MacLachlan, D. L. (2004). Responsive and proactive market orientation and new product success. Journal of Product Innovation Management, 21(5), 334-347. doi:10.1111/j.07376782.2004.00086.x

Neilson, G. L., Martin, K. L., \& Powers, E. (2008). The secrets to successful strategy execution. Harvard Business Review, 86(6). Retrieved from http://hbrbr.com.br/

Noble, C. H., \& Mokwa, M. P. (1999). Implementing marketing strategies: Developing and testing a managerial theory. Journal of Marketing, 63(4), 57-73. doi:10.2307/1251974

Nohria, N., Joyce, W., \& Roberson, B. (2003). What really works: Audio-Tech Business Book Summaries.

O Reilly, C. A., \& Tushman, M. L. (2004). The ambidextrous organization. Harvard Business Review, 82(4). Retrieved from http://hbrbr.com.br/

Olson, E. M., Slater, S. F., \& Hult, G. T. M. (2005a). The importance of structure and process to strategy implementation. Business Horizons, 48(1), 47-54. doi:10.1016/j.bushor.2004.10.002

Olson, E. M., Slater, S. F., \& Hult, G. T. M. (2005b). The performance implications of fit among business strategy, marketing organization structure, and strategic behavior. Journal of marketing, 69(3), 49-65.

Piercy, N. (2009). Market-led strategic change: A guide to transforming the process of going to market. New York, USA: Routledge.

Porter, M. E. (1980). Competitive strategies: Techniques for analyzing industries and competitors. New York, USA: The Free Press..

Quinn, R. E., \& Rohrbaugh, J. (1983). A spatial model of effectiveness criteria: Towards a competing values approach to organizational analysis. Management Science, 29(3), 363-377. 10.1287/mnsc.29.3.363

Slater, S. F., \& Narver, J. C. (1994). Does competitive environment moderate the market orientation-performance relationship? Journal of Marketing, 58(1), 46-55. doi:10.2307/1252250

Slater, S. F., \& Olson, E. M. (2000). Strategy type and performance: The influence of sales force management. Strategic Management Journal, 21(8), 813-829. doi:10.1002/1097-0266(200008)21:8<813::aid-smj122>3.0.co;2-g

Slater, S. F., \& Olson, E. M. (2001). Marketing's contribution to the implementation of business strategy: An empirical analysis. Strategic Management Journal, 22(11), 1055-1067. doi:10.1002/smj.198

Slater, S. F., Hult, G. T. M., \& Olson, E. M. (2007). On the importance of matching strategic behavior and target market selection to business strategy in high-tech markets. Journal of the Academy of Marketing Science, 35(1), 5-17. doi:10.1007/s11747-006-0002-4

Slater, S. F., Hult, G. T. M., \& Olson, E. M. (2010). Factors influencing the relative importance of marketing strategy creativity and marketing strategy implementation effectiveness. Industrial Marketing Management, 39(4), 551-559. doi:10.1016/j.indmarman.2008.03.007

Teece, D. J., Pisano, G., \& Shuen, A. (1997). Dynamic capabilities and strategic management. Strategic Management Journal, 18(7), 509533. 
Varadarajan, P. R., \& Clark, T. (1994). Delineating the scope of corporate, business, and marketing strategy. Journal of Business Research, 31(2-3), 93-105. doi:10.1016/0148-2963(94)90074-4

Varadarajan, P. R., Jayachandran, S., \& White, J. C. (2001). Strategic interdependence in organizations: Deconglomeration and marketing strategy. Journal of Marketing, 65(1), 15-28. doi:10.1509/ jmkg.65.1.15.18129

Vorhies, D. W., \& Morgan, N. A. (2005). Benchmarking marketing capabilities for sustainable competitive advantage. Journal of Marketing, 69(1), 80-94. doi:10.1509/jmkg.69.1.80.55505
Walker Jr, O. C., \& Ruekert, R. W. (1987). Marketing's role in the implementation of business strategies: A critical review and conceptual framework. Journal of Marketing, 51(3), 15-33. doi:10.2307/1251645

Wind, Y., \& Robertson, T. S. (1983). Marketing strategy: New directions for theory and research. Journal of Marketing, 47(2), 12-25. doi:10.2307/1251490

Workman Jr, J. P., Homburg, C., \& Gruner, K. (1998). Marketing organization: An integrative framework of dimensions and determinants. Journal of Marketing, 62(3), 21-41. 